\title{
Anticonvulsant Effects of Mu (DAGO) and Delta (DPDPE) Enkephalins in Rats ${ }^{1}$
}

\author{
FRANK C. TORTELLA, EDDIE ECHEVARRIA, LYDIA ROBLES, \\ HENRY I. MOSBERG* AND JOHN W. HOLADAY \\ Neuropharmacology Branch, Department of Medical Neurosciences \\ Division of Neuropsychiatry, Walter Reed Army Institute of Research, Washington, DC 20307 \\ and ${ }^{*}$ College of Pharmacy, University of Michigan, Ann Arbor, MI 48109
}

Received 1 April 1988

\begin{abstract}
TORTELLA, F. C., E. ECHEVARRIA, L. ROBLES, H. I. MOSBERG AND J. W. HOLADAY. Anticonvulsant effects of $m u(D A G O)$ and delta (DPDPE) enkephalins in rats. PEPTIDES 9(5) 1177-1181, 1988.-The effects of highly selective mu and delta opioid peptide agonists were determined in two rat models of experimentally-induced convulsions, the flurothyl threshold test and the maximal electroshock test. Intracerebroventricular injections of the mu selective enkephalin DAGO $(0.3-2.2 \mathrm{nmol})$ resulted in a dose-related protection in both seizure models. Pretreatment with a low dose of naloxone (29 nmol) or the irreversible mu antagonist $\beta$-FNA $(21 \mathrm{nmol})$, but not the delta opioid antagonist ICI $154,129(50 \mathrm{nmol})$, antagonized the anticonvulsant actions of DAGO. Intracerebroventricular injections of the delta selective enkephalin DPDPE (70-140 nmol) also resulted in seizure protection. These effects were selectively antagonized by the delta antagonist ICI $174,864(2.8 \mathrm{nmol})$, but not by pretreatment with $\beta$-FNA. Thus, using agonists and antagonists highly selective for mu and delta opioid receptors, anticonvulsant actions of enkephalin have been described against chemicallyand electrically-induced convulsions in rats.
\end{abstract}

Anticonvulsant effects DAGO DPDPE

SINCE the initial discovery of an anticonvulsant action of opioid peptides in the rat (32) numerous reports have described protective effects of opioid peptides in several animal models of experimental epilepsy (28). Moreover, the anticonvulsant properties of these peptides can be recognized as specific for opioid receptors since their actions were antagonized by naloxone or other opioid antagonists (28).

It has been well established that the pharmacological actions of opioids are not mediated by a homogenous receptor population, but instead involve at least four receptor subtypes (mu, delta, kappa, and sigma) $(14,20,46)$. It is therefore likely that the anticonvulsant actions of opioid peptides are also mediated via specific subtypes of opioid receptors. For example, previous studies using selective antagonists for mu and delta receptors demonstrated that the increase in convulsive threshold in rats produced by the mixed mu- and delta-directed opioid etorphine and D-Ala ${ }^{2}$-D-Leur-enkephalin (DADLE) were predominantly, but not exclusively, mediated by mu and delta receptors, respectively (36). More recently, anticonvulsant effects have been described for the kappa opioid peptide dynorphin $(3,11,29)$ and the nonpep- tide kappa U50,488 $(34,41)$. Hence, it would appear that mu, delta and kappa opioid receptors are all capable of producing anticonvulsant activity in the central nervous system (CNS).

The purpose of the present study was to evaluate more thoroughly the role of mu and delta opioid receptors in the anticonvulsant actions of enkephalin. For this purpose, the rat flurothyl and maximal electroshock (MES) tests were used to study the effects of the most highly selective enkephalin ligands presently available for mu and delta bindings sites, namely D-Ala ${ }^{2}-\mathrm{N}$-methyl-Phe ${ }^{4}-\mathrm{Gly}^{5}$-ol-enkephalin (DAGO) $(12,17,18)$ and D-Pen ${ }^{2}-D-P^{5}{ }^{5}$-enkephalin (DPDPE) $(17,22,23)$.

\section{METHOD}

Male Sprague-Dawley rats $(225-275 \mathrm{~g})$ obtained from Zivic-Miller Laboratories (Pittsburgh, PA) were anesthetized with ketamine $\mathrm{HCl}(100 \mathrm{mg} / \mathrm{kg}$, IP) and stereotaxically implanted with an ICV cannula aimed at the right lateral ventricle. Three to five days postsurgery, the animals were randomly assigned to control or treatment groups for testing.

${ }^{1}$ Preliminary reports of this work were presented at the annual meetings of the American Society of Pharmacology and Experimental Therapeutics, Baltimore, MD, 1986 and the Federation of American Societies for Experimental Biology, Washington, DC, 1987. 

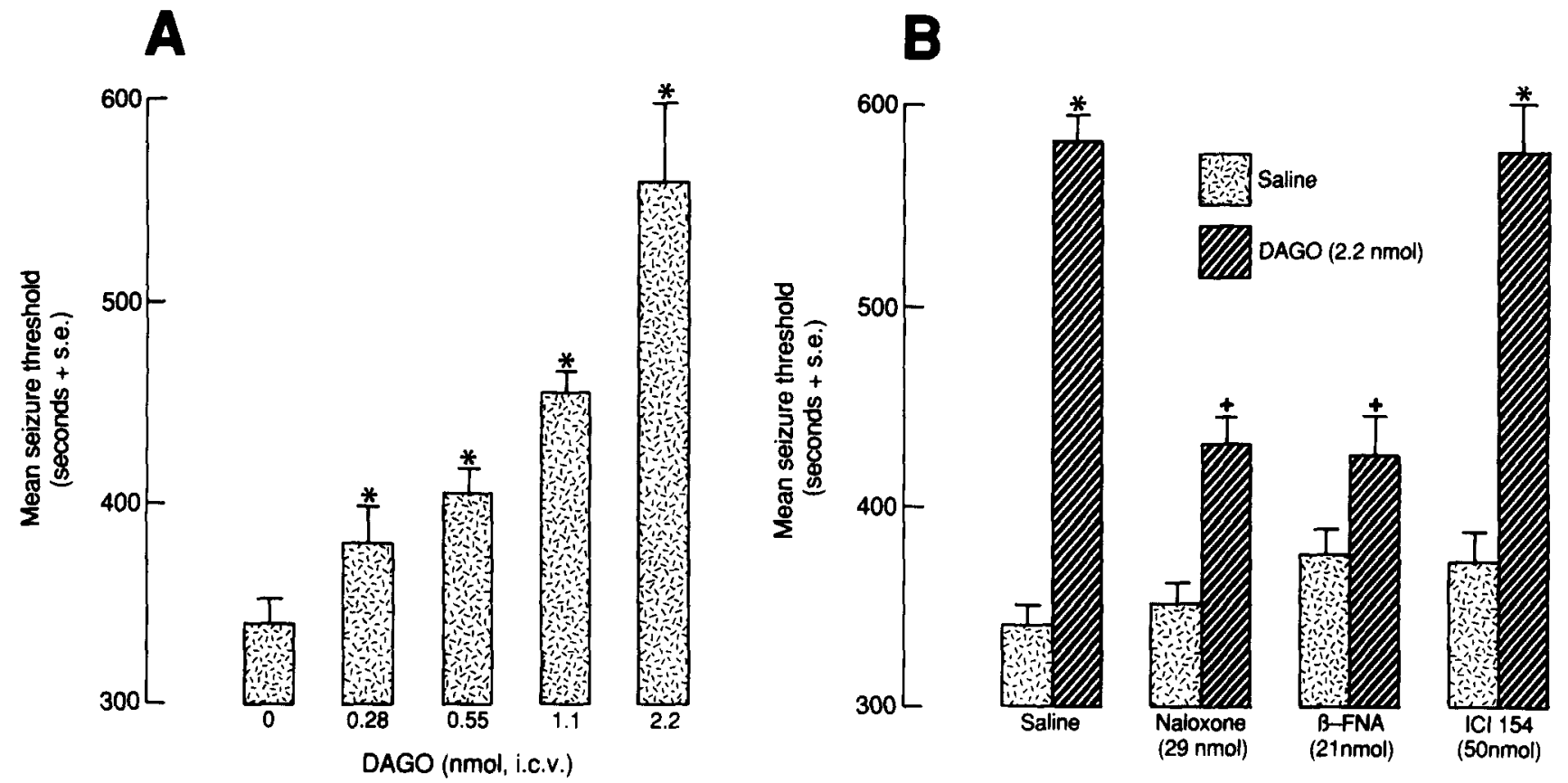

FIG. 1. (A) Anticonvulsant effect of DAGO against flurothyl convulsions. ${ }^{*} p<0.05$ compared to saline controls (ANOVA, Dunnett's test). (B) Effects naloxone, $\beta$-FNA or ICI 154,129 to antagonize the DAGO-induced increase in seizure threshold. ${ }^{*} p<0.05$ compared to corresponding saline group and $+p<0.05$ compared to DAGO alone (Student's $t$-test).

For seizure threshold studies, rats were individually exposed to the volative convulsant flurothyl, and the latency to a generalized convulsion with loss of posture was determined as previously described (34). MES convulsions were induced by transauricular electrical stimulation using a Wahlquist shock apparatus (Wahlquist Inst. Co., Salt Lake City, UT). Stimulus parameters were $50 \mathrm{~mA}$ for $2 \mathrm{sec}$ at $60 \mathrm{~Hz}$, producing a suprathreshold generalized convulsion (34).

Thirty min prior to testing, separate groups of rats $(n=6-$ 14 per group) received either a single ICV injection of saline (5 or $10 \mu \mathrm{l}$ ), DAGO (0.3-2.2 nmol) or DPDPE (70 or 140 $\mathrm{nmol}$ ) followed by a $2 \mu \mathrm{l}$ saline flush. The animals were then subjected to either flurothyl or MES, and the mean seizure threshold (ST) to a flurothyl-induced convulsion, or the presence or absence of MES-induced tonic hindlimb extension (THE), was recorded.

In separate experiments, the opioid receptor specificity of the response was determined using the nonselective antagonist naloxone $(29 \mathrm{nmol})$, the selective irreversible $\mathrm{mu}$ antagonist $\beta$-funaltrexamine $(\beta$-FNA; $21 \mathrm{nmol})(27)$, or the selective delta antagonists $\mathrm{N}, \mathrm{N}$-Bisally-Tyr-Gly-Gly- $\psi$ $\left(\mathrm{CH}_{2} \mathrm{~S}\right)$-Phe-Leu-OH (ICI 154,$\left.129 ; 50 \mathrm{nmol}\right)(6,39)$ and $\mathrm{N}, \mathrm{N}$-Bisallyl-Tyr-Aib-Aib-Phe-Leu-OH (ICI 174,864; 2.8 nmol) (25). In these studies, naloxone, ICI 174,864 and ICI 154,129 were administered ICV 5 min prior to the agonists; $\beta$-FNA was administered ICV $18-20 \mathrm{hr}$ prior to the agonists.

With the exception of ICI 174-864, all the compounds used in the study were dissolved in saline immediately prior to testing. ICI 174,864 was dissolved in $0.1 \mathrm{M}$ sodium bicarbonate. Throughout the study, control groups received the appropriate vehicle injection and, each animal was used only once. DPDPE was synthesized by Dr. H. I. Mosberg. DAGO was purchased from Peninsula Laboratories, Inc. (San Carlos, CA). Naloxone was a gift of Endo DuPont (Wilmington,
DE). $\beta$-FNA and ICI 174,864 and 154,129 were gifts from the National Institute on Drug Abuse and ICI Pharmaceuticals (Macclesfield, UK), respectively.

\section{RESULTS}

\section{Effects of Enkephalin Analogs Against Flurothyl Convulsions}

The effects of DAGO or DPDPE on flurothyl ST are shown in Figs. 1A and 3. Baseline STs for the DAGO and DPDPE control groups were $340 \pm 12 \mathrm{sec}$ (Fig. 1A) and $337 \pm 7 \mathrm{sec}$ (Fig. 3), respectively. ICV injections of DAGO produced a significant, dose-related increase in ST, reaching a maximum of $65 \%$ above control $(559 \pm 38 \mathrm{sec})$ at the highest dose tested (Fig. 1A). The administration of DPDPE also resulted in a significant, dose-dependent increase in the convulsive threshold to flurothyl. However, in these rats, ST was only increased approximately $15-20 \%$ above control $(389 \pm 12 \mathrm{sec})$ at the highest dose of DPDPE tested (Fig. 3). It is important to note that doses of DPDPE greater than 140 nmol $(98 \mu \mathrm{g})$ were not used since preliminary experiments revealed that higher doses of DPDPE $(125-150 \mu \mathrm{g}$, ICV) caused nonopioid behaviors in rats, characterized by barrelrolling and postural abnormalities.

\section{Effects of Enkephalin Analogs Against MES Convulsions}

In saline-treated animals, MES produced THE in 80$100 \%$ of the animals tested (Fig. $2 \mathrm{~A}, \mathrm{~B}$ and Fig. 4). ICV administered DAGO produced a significant anticonvulsant effect against MES convulsions, causing a dose-related blockade of THE. At the highest dose tested, only $10 \%$ of the animals demonstrated THE (Fig. 2A). A significant blockade 

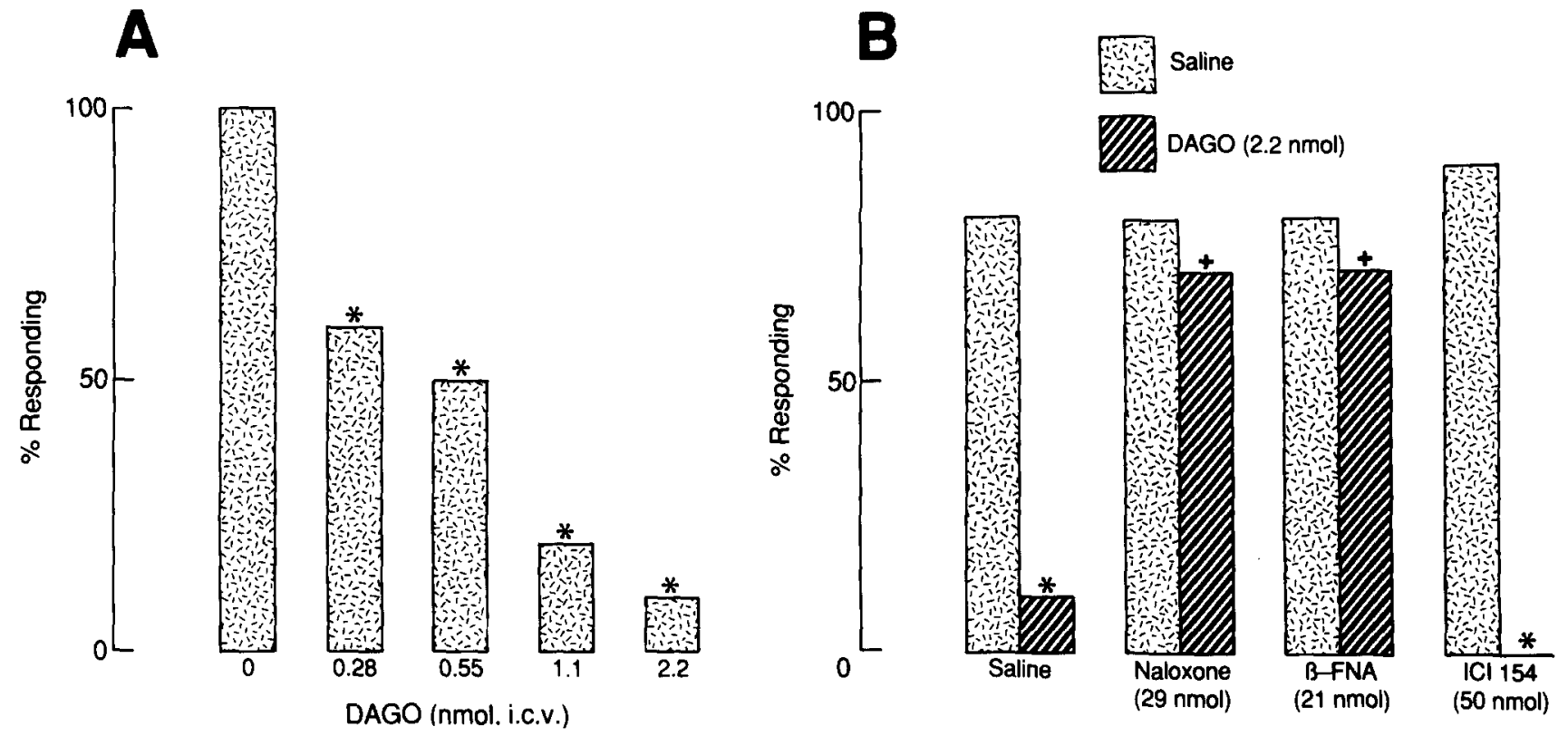

FIG. 2. (A) Anticonvulsant effect of DAGO against MES convulsions. ${ }^{*} p<0.05$ compared to saline controls (ANOVA, Mann-Whiney U-test). (B) Effects of naloxone, $\beta$-FNA or ICI 154,129 to antagonize the DAGO-induced blockade of THE. ${ }^{*} p<0.05$ compared to corresponding saline group and $+p<0.05$ compared to DAGO alone (Mann-Whitney U-test).

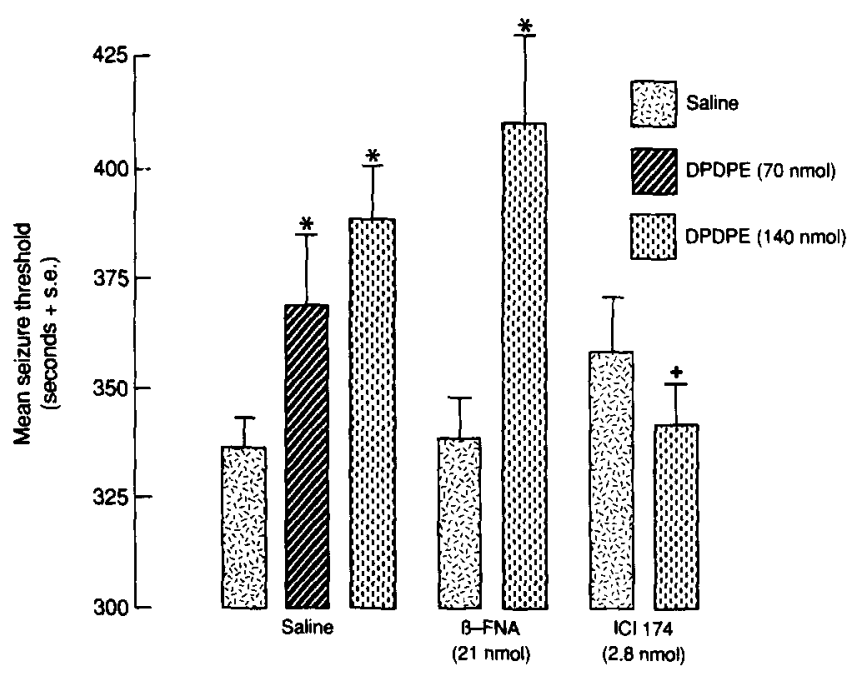

FIG. 3. Anticonvulsant effect of DPDPE against flurothyl convulsions and antagonism by $\beta$-FNA or ICI $174,864 .{ }^{*} p<0.05$ compared to saline controls and $+p<0.05$ compared to DPDPE alone (Student's $t$-test).

of seizure spread also occurred following injections of DPDPE. Complete blockade of THE was observed in $50 \%$ of the animals tested (Fig. 4).

\section{Effects of Opioid Antagonists}

ICV injections of naloxone, $\beta$-FNA, ICI 174,864 or ICI 154,129 had no significant effect on flurothyl STs (Figs. $1 B$ and 3) or MES-induced THE (Figs. 2B and 4). However,

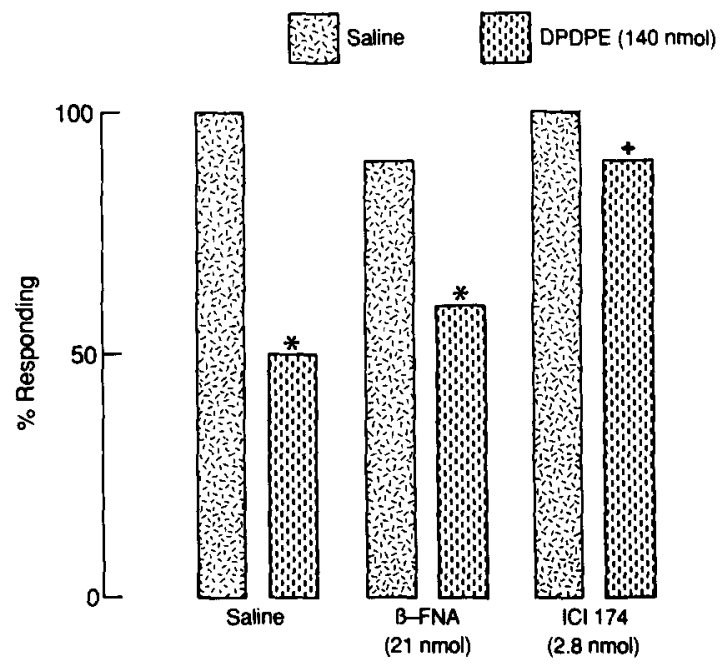

FIG. 4. Anticonvulsant effect of DPDPE against MES convulsions and antagonism by $\beta$-FNA or ICI $174,864 .{ }^{*} p<0.05$ compared to saline controls and $+p<0.05$ compared to DPDPE alone (MannWhitney U-test).

in both seizure tests, the anticonvulsant effects of $2.2 \mathrm{nmol}$ DAGO were significantly antagonized by naloxone or $\beta$-FNA. In this regard, the DAGO-induced increase in ST was reduced from $559 \pm 38 \mathrm{sec}$ to $432 \pm 25 \mathrm{sec}$ and $426 \pm 20 \mathrm{sec}$ by naloxone $(29 \mathrm{nmol})$ and $\beta$-FNA $(21 \mathrm{nmol})$ pretreatment, respectively (Fig. 1B). Similarly, DAGO-induced blockade of THE was completely attenuated by these doses of antagonists (Fig. 2B). In contrast, pretreatment with ICI $154,129(50 \mathrm{nmol})$ failed to antagonize the anticonvulsant effects of DAGO in either seizure test (Figs. 1B and 2B). 
In the flurothyl and MES tests, the anticonvulsant properties of DPDPE were antagonized by ICI 174,864 (2.8 nmol), but not $\beta$-FNA (21 nmol). Here, pretreatment with the delta antagonist returned DPDPE-induced increases in flurothyl ST ( $389 \pm 12 \mathrm{sec}$ ) to control levels ( $342 \pm 11 \mathrm{sec}$ ) (Fig. 3 ), and completely antagonized the DPDPE-induced blockade of MES-induced THE (Fig. 4). As seen in Figs. 3 and 4, $\beta$-FNA failed to antagonize the anticonvulsant effects of DPDPE in either seizure test. Naloxone was not tested in DPDPE-treated rats.

\section{DISCUSSION}

Studies of CNS excitability in several animal species and experimental models have shown that the seizure protective effects of opioid peptides are due to specific interactions with central opioid receptors [see (28) for review]. The present study confirms and further extends these findings by demonstrating that enkephalins highly selective for mu and delta binding sites are anticonvulsant in the rat. Furthermore, the selectivity of their anticonvulsant actions at mu and delta receptors was demonstrated using specific opioid receptor antagonists.

The agonist DAGO and the antagonist $\beta$-FNA have been previously shown to be selective for mu opioid receptors (12, $17,18,27,36,38$ ) while the agonist DPDPE and the antagonist compounds ICI 154,129 and ICI 174,864 represent the most selective ligands for delta opioid sites $(6,17,22,23$, $25,27,38$ ). Thus, our results demonstrating that DAGO or DPDPE will protect rats against convulsions, and that these effects can be selectively blocked by their respective opioid antagonists, suggest that both mu and delta opioid receptors mediate the anticonvulsant properties of these ligands in the flurothyl and MES seizure models. More recently, the results of experiments using morphine and DAGO have implicated mu receptors (but not delta) in the effect of opioids to limit kindled amygdaloid seizures (2).

These data are reinforced by other observations that mu and delta opioid receptors are involved in the opioid control of seizure protection. For example, the anticonvulsant effects of DADLE and etorphine were shown to be antagonized by ICI 154,129 and $\beta$-FNA, respectively (36), while other pharmacological studies have demonstrated anticonvulsant effects of synthetic agonist analogs of enkephalin which possess mixed mu and delta receptor selectivities (5, $28,37)$.

The anticonvulsant properties of opioid peptides are of significant importance in characterizing the endogenous regulation or pharmacological control of seizure activity. Initial observations that opioid peptides produced nonconvulsive EEG seizure patterns in rats $(12,35,40)$ resulted in speculation as to their possible role in the pathophysiology of epilepsy. Thus, it was originally suggested that the endogenous peptides may in fact be epileptogenic (40), not anticon- vulsant as the present results suggest. However, with few exceptions (see below), the proconvulsant properties of opioid peptides appear to be relatively insensitive to opioid antagonists, generally requiring doses of naloxone in the order of $2-10 \mathrm{mg} / \mathrm{kg}$ (or greater) before even partial antagonism can be seen. These observations suggest that the proconvulsant actions may be due to nonspecific (high dose) effects, possibly involving nonopioid systems $(9,28)$. Alternatively, the results of several electrophysiological studies indicate that these epileptogenic responses result from an effect of mu opioid peptides to indirectly excite hippocampal function through disinhibition of inhibitory interneurons $(4,10,45)$. In support of this we (38) and others (19) have recently demonstrated that the nonconvulsive EEG seizures resulting from the ICV administration of enkephalin (38), or generalized convulsions produced by intrahippocampal injections of enkephalin (19), are mediated by specific interactions with the mu receptor subtype. Therefore, under certain experimental conditions, epileptogenic properties can be demonstrated for mu selective opioid peptides. It is unlikely however that delta or kappa opioids modulate epileptogenic activity since EEG seizures or generalized convulsions have not been associated with injections of DPDPE and DPLPE $(38)$, dynorphin $(1,42)$, or the selective nonpeptide kappa opioid U50,488 $(34,41)$ (F. C. Tortella, unpublished observation).

In contrast to the putative proconvulsant actions of opioid peptides, their inhibitory anticonvulsant effects in numerous species and experimental models clearly represent specific, receptor-mediated properties of their general pharmacology (28). Additionally, rather than endogenous opioid systems activating seizures, studies using behavioral, EEG, receptor binding, immunohistochemical and radioimmunoassay endpoints have clearly established the converse; i.e., that seizures activate endogenous opioid systems $(5,15,21,28$, 33). Consequently, it has been proposed that the seizure activation of endogenous opioids may function to "turn-off' ' or self-limit convulsive behaviors $(5,28,33)$. The recent identification of an opioid peptide-like endogenous anticonvulsant substance in rat CSF following a generalized convulsion supports this hypothesis $(30,31)$.

Results of the present study and others $(3,11,34,41)$ demonstrate that opioid peptides with pharmacological selectivity for mu, delta, and kappa binding sites are anticonvulsant. It is interesting to note that mu, delta and kappa opioids selectively hyperpolarize neurons throughout the CNS $(7,8,44)$ and that endogenous opioids are localized in fiber tracts throughout the brain and spinal cord that are involved in the generation and spread of seizure activity (16, $21,24,26,43)$. Therefore, it seems possible that opioid peptides may indeed function as endogenous anticonvulsants in the CNS, modulating the underlying mechanisms of seizure arrest and refractoriness which are critical to the suppression of convulsions.

\section{REFERENCES}

1. Adler, M. W.; Tortella, F. C. Dissimilar EEG and behavioral effects of $\beta$-endorphin and dynorphin $1-13$ in rats. Pharmacologist 25:152; 1983

2. Bohme, G. A.; Stutzman, J.-M.; Roques, B. P.; Blanchard, J.-C. Effects of selective mu- and delta-opioid peptides on kindled amygdaloid seizures in rats. Neurosci. Lett. 74:227-231; 1987.
3. Bonhaus, D. W.; Rigsbee, L. C.; McNamara, J. O. Intranigral dynorphin 1-13 suppresses kindled seizures by a naloxoneinsensitive mechanism. Brain Res. 405:358-363; 1987.

4. Bostock, E.; Dingledine, R.; Chang, K.-J. Mu opioid receptors participate in the excitatory effect of opiates in the hippocampal slice. J. Pharmacol. Exp. Ther. 231:512-517; 1984. 
5. Caldecott-Hazard, S.; Engel, J. Limbic postictal events: Anatomical substrates and opioid receptor involvement. Prog. Neuropsychopharmacol. Biol. Psychiatry 11:389-418; 1987.

6. Cotton, R.; Giles, M. G.; Miller, L.; Shaw, J. S.; Timms, D. ICI174,864: A highly selective antagonist for the opioid delta receptor. Eur. J. Pharmacol. 97:331-332; 1984.

7. Dickenson, A. H.; Sullivan, A,; Feeney, C.; Fournie-Zaluski, M. C.; Roques, B. P. Evidence that endogenous enkephalins produce delta-opiate receptor mediated neuronal inhibitions in rat dorsal horn. Neurosci. Lett. 72:179-182; 1986.

8. Duggan, A. W.; North, R. A. Electrophysiology of opioids. Pharmacol. Rev. 35:219-281; 1984.

9. Frenk, H. Pro- and anticonvulsant actions of morphine and the endogenous opioids: Involvement and interactions of multiple opiate and non-opiate systems. Brain Res. Rev. 6:197-210; 1983.

10. Gahwiler, B. H.; Maurer, R. Involvement of mu receptors in the opioid generation of bursting discharges in hippocampal pyramidal cells. Regul. Pept, 2:91-96; 1981.

11. Garant, D. S.; Gale, K. Infusion of opiate into the substantia nigra protects against maximal electroshock seizures in rats. J. Pharmacol. Exp. Ther. 234:45-48; 1985.

12. Handa, B. K.; Lane, A. C.; Lord, J. A. H.; Morgan, B. A.; Rance, M. J.; Smith, C. F. C. Analogs of beta-LPH-61-64 possessing selective agonists at mu-opiate receptors. Br. J. Pharmacol. 70:531-540; 1981

13. Henriksen, S. J.; Bloom, F. E.; McCoy, F.; Ling, N.; Guille$\min$, R. Beta-endorphin induces non-conclusive limbic seizures. Proc. Natl. Acad. Sci. USA 75:5221-5225; 1978.

14. Holaday, J. W.; Tortella, F. C.; Long, J. B.; Belenky, G. L.; Hitzemann, R. J. Endogenous opioids and their receptors: Evidence for involvement in the postictal effects of electroconvulsive shock. Ann. NY Acad. Sci. 462:124-139; 1987.

15. Holaday, J. W.; Tortella, F. C.; Meyerhoff, J. L.; Belenky, G. L.; Hitzemann, R. J. Electroconvulsive shock activates endog enous opioid systems: Behavioral and biochemical correlates. Ann. NY Acad. Sci. 467:249-255; 1987.

16. Hokfelt, T.; Elde, R.; Johansson, O.; Terenius, L.; Stein, L. The distribution of enkephalin-immunoreactive cell bodies in rat central nervous system. Neurosci. Lett. 5:25-31; 1977.

17. James, I. F.; Goldstein, A. Site-directed alkylation of multiple opioid receptors. I. Binding selectivity. Mol. Pharmacol. 25:337-342; 1984.

18. Kosterlitz, H. W.; Paterson, S. J. TYR-D-ALA2-GLYMePHE- $\mathrm{NH}(\mathrm{CH} 2) 2-\mathrm{OH}$ is a selective ligand for the mu opiate binding site. Br. J. Pharmacol. 73:299P; 1981

19. Lee, P. H. K.; Obie, J.; Hong, J. S. Intrahippocampal injections of a specific mu receptor ligand PL017 produce generalized convulsions in rats. Brain Res., in press; 1988

20. Lord, J. A. H.; Waterfield, A. A.; Hughes, J.; Kosterlitz, H. W. Endogenous opioid peptide: Multiple agonists and receptors. Nature 267:495-499; 1977.

21. McGinty, J. F.; Kanamatsu, T.; Obie, J.; Dyer, R. S.; Mitchell, C. L.; Hong, J. S. Amygdaloid kindling increases enkephalinlike immunoreactivity but decreases dynorphin-A-like immunoreactivity in rat hippocampus. Neurosci. Lett. 71:31-36; 1986.

22. Mosberg, H. I.; Hurst, R.; Hruby, V. J.; Gee, K.; Yamamura, H. I.; Galligan, J. J.; Burks, T. F. Bis-penicillamine enkephalins show pronounced delta opioid receptor selectivity. Proc. Natl. Acad. Sci. USA 80:6871-6874; 1983.

23. Porreca, F.; Mosberg, H. I.; Hurst, R.; Hruby, V. J.; Burks, T. F. Roles of mu, delta and kappa opioid receptors in spinal and supraspinal mediation of gastrointestinal transit and hot-plate analgesia in the mouse. J. Pharmacol. Exp. Ther. 230:341-348; 1984.

24. Sar, M.; Stumpf, W. E.; Miller, R. J.; Chang, K.-J.; Cuatracasas, $\mathrm{P}$. Immunohistochemical localization of enkephalin in the rat brain and spinal cord. J. Comp. Neurol. 44:501-512; 1986

25. Shaw, J. S.; Miller, L.; Turnbull, M. J.; Gormley, J. J.; Morley, J. S. Selective antagonists at the opiate delta receptor. Life Sci. $31: 1259-1262 ; 1982$.
26. Siggins, G. S.; Henriksen, S. J.; Chavkin, C.; Groul, D. Opioid peptides and epileptogenesis in the limbic system: Cellular mechanisms. Adv. Neurol. 44:501-512; 1986.

27. Takemori, A. E.; Larsen, D. L.; Portoghese, P. S. The irreversible narcotic anatagonist and reversible agonist properties of the fumaramate ester methyl derivative of naltrexone. Eur. J. Pharmacol. 70:445 451; 1981.

28. Tortella, F. C. Opioid peptides: possible physiological role as endogenous anticonvuisants. In: Ferrendelli, J.; Collins, R.; Johnson, E., eds. Neurobiology of amino acids, peptides and trophic factors. Boston: Kluwer Academic; 1988:163-179.

29. Tortella, F. C.; Holaday, J. W. Dynorphin (1-13): In vivo antagonist actions and non-opioid anticonvulsant effects in the rat flurothyl test. NIDA Monogr. 75:539-542; 1986.

30. Tortella, F. C.; Long, J. B. Endogenous anticonvulsant substance in rat cerebrospinal fluid after a generalized seizure. Science 228:1106-1108; 1985.

31. Tortella, F. C.; Long, J. B. An endogenous opioid-like substance regulates neuronal excitability: Characterization of its anticonvulsant properties. Neurol. Neurobiol. 28:33-40; 1987.

32. Tortella, F. C.; Cowan, A.; Adler, M. W. Comparison of the anticonvulsant effects of opioid peptides and etorphine in rats. Life Sci. 29:1039-1045; 1981.

33. Tortella, F. C.; Long, J. B.; Holaday, J. W. Endogenous opioid systems: Physiological role in the self-limitation of seizures. Brain Res. 332:174-178; 1985.

34. Tortella, F. C.; Robles, L.; Holaday, J. W. U50,488, a highly selective kappa opioid: Anticonvulsant profile in rats. J. Pharmacol. Exp. Ther. 237:49-53; 1985.

35. Tortella, F. C.; Moreton, J. E.; Khazan, N. Electroencephalographic and behavioral effects of D-ALA2-methionineenkephalinamide and morphine in the rat. J. Pharmacol. Exp. Ther. 206:636-643; 1978.

36. Tortella, F. C.; Robles, L.; Holaday, J. W. The anticonvulsant effects of DADLE are primarily mediated by activation of delta opioid receptors: Interactions between delta and mu receptor antagonists. Life Sci. 37:497-503; 1985.

37. Tortella, F. C.; Robles, L.; Holaday, J. W.; Cowan, A. A selective role for delta receptors in the regulation of opioid-induced changes in seizure threshold. Life Sci. 33:603-606; 1983.

38. Tortella, F. C.; Robles, L.; Mosberg, H. I. Evidence for mu opioid receptor mediation of enkephalin-induced electroencephalographic seizures. J. Pharmacol. Exp. Ther. 240:571-577; 1987.

39. Tortella, F. C.; Robles, L.; Holaday, J. W.; Cowan, A. ICI154,129, a delta opioid receptor antagonist raises seizure threshold in rats. Eur. J. Pharmacol. 97:141-144; 1984.

40. Urca, G.; Frenk, H.; Liebeskind, J. C.; Taylor, A. N. Morphine and enkephalin: Analgesic and epileptogenic properties. Science 197:83-86; 1977.

41. VonVoightlander, P. F.; Hall, E. D.; Camacho, O.; Lewis, R. A.; Triezenberg, H. J. U-54494A: A unique anticonvulsant related to kappa opioid agonists. J. Pharmacol. Exp. Ther. 243:542-547; 1988.

42. Walker, J. M.; Moises, H. C.; Coy, D. H.; Baldrighi, G.; Akil, H. Nonopiate effects of dynorphin and Des-Tyr-dynorphin. Science 218:1136-1138; 1982

43. Wamsley, J.; Young, W.; Kuhar, M. Immunohistochemical localization of enkephalin in rat forebrain. Brain Res. 190:153$174 ; 1980$.

44. Werz, M. A.; MacDonald, R. L. Dynorphin and neoendorphin peptides decrease dorsal root ganglion neuron calcium. dependent action potential duration. J. Pharmacol. Exp. Ther. 234:49-56; 1985.

45. Williams, J. T.; North, R. A. Opiate receptor interactions on single locus coerleus neurones. Mol. Pharmacol. 26:489-497; 1984.

46. Wuster, M.; Schultz, R.; Herz, A. Multiple opiate receptors in peripheral tissue preparations. Biochem. Pharmacol. 30:1883$1887 ; 1981$. 